\title{
STUDENT INTEREST IN CONTINUING STUDIES INTO HIGHER EDUCATION INFLUENCED BY SEVERAL FACTORS: FAMILY ECONOMIC STATUS, TYPE OF SCHOOL AND SCHOOL STATUS
}

\author{
Nurandi Jopa ${ }^{1}$ \\ Gatot Sugeng Purwono ${ }^{2}$ \\ Hary Sulaksono ${ }^{3}$ \\ Higher Education of Economic Mandala \\ e-mail: mochjoe@yahoo.co.id
}

\begin{abstract}
This research aims to identify and analyze: 1) The influence of economic status of family, type of school and school status simultaneously against student interest in continuing their studies to university; 2) Effect of family economic status partially on student interest in continuing study on higher education; 3) The influence of type of school partially on student interest in continuing study on higher education; 4) Effect of school status partially on student interest in continuing study on higher education; and 5) Which variable is more dominant in influencing student interest in continuing study to college on students in Secondary School level in the Kedaleman Village, Rogojampi Sub-district, Banyuwangi District. The sampling technique used incidental technique and Snowball sampling as many as 50 students. The data collection technique utilized questionnaire and documentation. The questionnaire method is applied to collect data of independent and the dependent variable. The try out of research instrument were using validity and reliability test. Data analysis technique used is the technique of Binary Logistic Regression Analysis. The results of this study were: 1) The economic status of the family, the type of school and school status simultaneously have a significant influence on student interest in continuing study to higher education; 2) Family economic status partially has a significant impact on student interest in continuing to study on higher education; 3) Type of school partially has a significant impact on students' interest in continuing their studies to higher education; 4) Status of school does not affect the students' interest in continuing their studies to higher education; and 5) The more dominant variables to affect the interest of students in higher education to continue their studies is variable economic status.
\end{abstract}

Keywords: Family Economic Status, Type of School, School Status, Student Interest in Continuing Studies 


\section{INTRODUCTION}

At the present time, the younger generations are required to have a high knowledge so that they are not left behind through the time. Every person must have a good quality in all aspects because the increasing demands and competitive work requires qualified human resources. Education is one way to improve human resources. With education a person will get a wide range of science such as pure and applied science. Education is basically a process to help people in developing themselves, so as to cope with any changes that occur in life.

According to Law No. 20 of 2003 on National Education System that "Secondary education in the form of Senior High School, Islamic High School, Vocational High School and Vocational Islamic High School or other equivalent form". The low perception of education is able to decrease the interest of the students who want to apply for college. Based on the observation of the students of vocational schools on the surrounding community, they expect after graduating in secondary vocational school they can directly having a job so it does not need to continue to pursue a higher education. In the opposite side, from the first the students at the senior high school project themself in order to continue their education to college because the school environment is conducive to proceed study. But there is still a possibility that students will prefer to work or do not continue their studies to university.

The students background is to be a separate consideration in reaching future goals. Sometimes school status also contributed as an obstruction for students to continue their studies. In accordance with Government Regulation No. 29 of 1990 on Secondary Education Article 13, about the difference of private and public schools that if public schools, all matters concerning the school would be regulated by the government, while private schools will be organized by community organizations and it is commonly in the form of a foundation, but must remain within the rules or standards of government. From here, students from public schools will be more motivated to continue the study because the environment will indirectly attract students willingness to continue their studies to university. It is a different matter with private school students. They sometimes had to get their information about the college, while the environment shows negative impact because most students who study at private schools are likely choose to work rather than continue their studies to university.

Another factor which can determine the success of someone's education is due to the economic status in the family environment. According Sugihartono (2007: 30) "Socio-economic status of parents can be seen from the level of their education, occupation, and income". Today, it is required a lot of scholarships offered by the government exclusively reserved for students from economically disadvantaged families, but they must also prepare loan fund for temporary living expenses while waiting for the process of receiving the scholarship. In order to continue to higher levels of education, it is required proper infrastructure and equipments, and to meet those all, funds are needed. Problem of funds 
availability to proceed the higher level education is closely related to the economic status in the family environment. It makes the economic status in the family environment become one of external factor about the emergence of interest in continuing education to a higher level.

Motivation of pursuing education to college needs to be grown on each of student. According Muhibin Syah (2000: 175) motivation to continue their studies to university means students interest to continue their studies to university that grow consciously amongst them. That motivation makes students give more attention to their preference college. Students who have an interest to pursue a higher education will have a sense of fun, attention, interest and willingness to work harder, so that they can compete with other students. That interest can grow on the perception of the students themselves about education.

The purpose of this study was to investigate and analyze: 1) The influence of family economic status, type of school and school status simultaneously on student interest in continuing to study higher education; 2) Effect of family economic status partially on student interest in continuing to study higher education;

3) The influence of school type partially on student interest in continuing to study higher education;

4) Effect of school status partially on student interest in continuing to study higher education; 5) The more dominant variable in influencing students' interest in continuing their studies to university.

\section{RESEARCH METHODS}

The object of this study is the community of Kedaleman village, Rogojampi Sub-district of Banyuwangi District who is still active as students. The study lasted for 2 months started in November and December 2016. This study is specifically intended for students of class XII because they will be passed beforehand and have to choose either to work or college. The sampling technique was conducted in Incidental technique and Snowball sampling, and involved 50 students as the samples. This type of research is in the form of quantitative research due to dealing with numbers. Identification of variables in this study is structured into two independent variables in the form of family economic status, type of school and school status, as well as the dependent variable that students' interest in continuing their studies to university. Methods of data collection using a questionnaire and documentation. While the methods of data analysis in this study using Binary Logistic Regression Analysis.

\section{RESULT ANALYSIS}

Based on the hypothesis, the research results are expected to show a significant effect of family economic status, type of school and school status of the student's interest in continuing their studies to university.

Before analyzing the data,
researchers conducted a test
instrument to test the validity and
reliability. After testing the
instrument, the results show that all
of the items on the questionnaire
used were valid with the value of
each item $<\alpha(0.100)$ and overall
items were very reliable with a value
of 0.808 which means that the level


of trust and reliability of the instrument indicates the consistencies of the items were very high.

It is done for data analysis, with the results as follows: 1) The economic status families, types of schools and school status simultaneously having a significant impact on students' interest in continuing their studies to university with p-valueChi-Square0.000 $<\alpha$ $(0.05)$, so it rejects Ho and accepts $\mathrm{H} 1$ and the influence of independent variables on the dependent variable of 0.609 or $60.9 \%$, while the remaining $39.1 \%$ is influenced by other variables outside of this study. 2) The economic status of families with the Sig. Wald $<\alpha ; \quad(0.001$ $<0.05)$, so it rejects Ho and accepts $\mathrm{H} 1$, resulting in partial economic status has a significant impact on students' interest in continuing their studies to university. 3) Type of school with the Sig. Wald $<\alpha ;(0.047$ $<0.05)$, so it rejects Ho and accepts $\mathrm{H} 1$, resulting in partial types of schools have a significant impact on students' interest in continuing their studies to university. 4) The status of the school with the Sig. Wald $>\alpha$; (0.300>0.05), so it accepts Ho and rejects $\mathrm{H} 1$, resulting in partial school status had no effect on students' interest in continuing their studies to university. 5) For a more dominant variable is a variable economic status by looking at the largest value in the column Exp (B) is 0.755 or notice the smallest value in column Sig. Wald is 0.001 .

\section{INTERPRETATION}

Based on the research, it is found that variable of partial economic status has a significant impact on students' interest in continuing their studies to university. Results were in tune with some of the previous studies conducted by Nabila Kharisma and Lyna Latifah (2015), Khoerunisa Fitriany (2014), Sulistiyorini Nurhadiyanti (2014), and Nanik Suryani (2006) all of which are equally stated that the socioeconomic status of parents has a significant influence on the interest of continuing education to college. This means that the better the economic status of the family that owned by the parents, the more increase of the students interest to continue their studies to university.

the research also shows that partially variable types of schools have a significant impact on students' interest in continuing their studies to university. Results were in tune with some of the previous studies conducted by Khoerunisa Fitriani (2014), and Ayu Dwi Febriani (2015) were both equally declare that the type / school environment occupied by students has a significant impact on students' interest in continuing education to college. At theories which have been put forward that logically students who come from public schools would have been inclined to continue their education to college. While students from vocational schools tend to choose to work rather than continuing study. Research shows that students who come from public schools have more interest to continue their studies to university than students from vocational schools.

Based on the research, it is found that variable of partial school status has no effect on students' interest in continuing their studies to university. Results were in line with the previous research conducted by 
Ayu Dwi Febriani (2015) which states that status does not affect the interest of the school to go to college, so students who attend public and private schools have the same probability to go to college. However, this study is contrary to research conducted by Ninuk Indriyanti, et al (2013), and Khoerunisa Fitriani (2014), which both are equally stated that the status of the school occupied by students have a significant impact on students' interest in continuing education to college. This means that difference kind of school which is public or private, cannot be used as a measure as evidence that students have an interest or not to continue their studies in college.

\section{CONCLUSIONS}

Based on test results and statistical analysis, it can be concluded that there are simultaneously a significant difference between the economic status of the family, school type and status of the school to the student's interest in continuing to study at college on the students of secondary level education in the Kedaleman village, Rogojampi Sub-district, Banyuwangi District. There is partially a significant difference between the economic statuses of the student's interest in continuing their studies to university. There is partially a significant difference between the types of school toward students' interest in continuing to higher education study. But the school status variables has no partial effect on students' interest in continuing their studies to university. And among the independent variables, there is a more dominant variable in influencing students' interest to continue their studies to higher education, which is variable of family economic status.

\section{IMPLICATIONS}

Based on the conclusions obtained in this study, there are some recommendations and follow-up as follows:

1. All of the independent variable (X) has a simultaneous effect on the dependent variable (Y). Based on earlier theories, students who come from established families, study at public schools, and comes from the popular school (state) will be easier to continue their education to a higher level, because the facilities acquired by the students, ranging from special needs to common needs are very easy to be obtained by students in order to achieve their wish.

2. Students who come from families that have more established economies will be easier to continue their education rather than students who come from poor families. However, in reality, many students who come from poor families also have been successful in continuing their education to a higher level with the help of a scholarship either from the local government or central government.

3. Public school in this case a senior high school / islamic high school prefers their students to be able to continue their education to college because senior high school implements theories in learning so that students are more motivated to study at university. In contrast to the vocational school that prefers to implement practical 
activities so that after graduation the students can directly work.

4. Public Schools administered by the government, while private schools are managed by the foundation. So sometimes public schools are preferred by the government rather than private schools, which have less complete learning facilities rather than public schools. However, this study proves that students from public and private schools have equal opportunity in determining the students to continue their education to a higher level.

5. The more dominant variable in this study is the family's economic status variables (X1) which has a greater impact than other variables. In another study, family economic status variables are always have a relationship and influence on the interests of students on continuing to college. 


\section{BIBLIOGRAPHY}

Adi Permana, Gina. 2010. Community Economic Group. Accessed through: https://ginanjaradp.wordpress .com/tag/golongan-ekonomimasyarakat/ on July 20, 2017

Agustina, Hilda. 2012. Definition of Human

ResourceManagement.Access ed through:

http://hildaagustina.blogspot. co.id/2012/01/pengertian-source-daya.html management on October 1, 2016

Algifari. 2013. Regression Analysis Theory, Cases, and Solutions. Yogyakarta: Yogyakarta BPFE

Alvianto, Jonah. 2013. Interest Students to College of Continuing Studies Background Judging from the Parent Education and Family Economic Status On Student Class XI IPS SMAN Colomadu Academic Year 2012/2013. Research journal. Surakarta: Muhammadiyah University ofSurakarta

Central Bureau of Statistics Banyuwangi. 2015.District of Rogojampi in Figures. Banyuwangi:

BPSBanyuwangi

Statistics AgencyBanyuwangi. 2016. Regional Statistics 2016. Rogojampi District of Banyuwangi: BPS Banyuwangi
Basu Swasta and Hani Handoko. 2014. Analysis of Consumer Behavior MarketingManagement.Yogy akarta: Yogyakarta BPFE

Cipta Ginting. 2003. Successful Learning at the University. Accessed through: http://zoetmeisje.doodlekit.co m/blog/entry/3759364/sukses -belajar-di-universitas- on July 21, 2017

Dian Setyo Haryono and Herlambang Sigit Pramono. 2013. Effects of Parenting Parents' Learning Achievement and Information College of Continuing Interest to College Students $N$ 2 Kebumen. Research journal. Yogyakarta: Yogyakarta State University

Dimyati Mahmud. 1989. EducationalPsychology.Jakar ta: Ministry of Education and Culture

Febriani, Ayu Dwi. 2015. Effect of Perception On Education, Environment Peers, Type of School and Educational Status Of Interest in Continuing Higher Education. Research journal. Yogyakarta: Yogyakarta State University

Gina Andanawari, Aden. 2010. Factors Affecting Student Interest in Continuing Education to the College by Using Logistic Regression. Thesis. Bogor Institute of Agriculture Bogor 
Harjiyono, Priyo. Books Work Research Methods Prof. Sugiyono. Accessed through: http://anotherorion.com/bukumetode-penelitian-karyaprof-sugiyono/ on October 1, 2016

Indriyanti, Ninuk, et al. 2013. Factors Affecting Interest in Continuing Education to College Students of Class XII Accounting SMK 6 Surakarta. Research journal. Surakarta: University Sebelas Maret of Surakarta

Ministry of the Education and Culture. 2016. Highlights of Education

Year2015/2016.Jakarta: Data and Statisticsof Education and Culture

Ministryof the Education and Culture.2016. Indonesia Educational

StatisticsinBrief.Jakarta: Data and Statistics of Education and Culture

Ministry of Research, Technology and Higher Education. 2015.Annual

Report,2015.Accessed through

http://ristekdikti.go.id/inform asi-publik/laporan-tahunan on October 1, 2016

Khoerunisa Fitriani. 2014. Effect of Motivation, Achievement, Socioeconomic Status of Parents and School Environment against Interest in Continuing Education to College Students of Class XII Accounting SMK Negeri
1Kendal.Research journal. Semarang: Semarang State University

Muhibin Syah. 2005. Educational Psychology with NewApproach.Bandung: Remaja Rosdakarya

M. Alisuf Sabri. 2007. Educational psychology. Jakarta: Pedoman Ilmu Jaya

M. $\quad 2005$. EducationalPsychology.Jakar ta: Rineka Cipta

Nabila Kharisma and Lyna Latifah. 2015. Effect of Motivation, Achievement, Socioeconomic Status of Parents and Peers against Environmental Interests College of Continuing Education to Class XII on Accounting Skills Competency in SMK Se-Semarang in Academic Year2014/2015.Research journal. Semarang: Semarang State University

Nanik Suryani. 2006. Influence of Social and Economic Conditions Motivation Parents to College of ContinuingEducation. Researc $\mathrm{h}$ journal. Semarang: Semarang State University

Nurhadiyanti, Sulistiyorini. 2014. Effect of Motivation and Socio-Economic Status Parents against Interest in Continuing Studies into Higher Education. Research journal. Yogyakarta: Yogyakarta State University 
Nurjaman, Aditia. 2014. Effect of Achievement, Parenting and Parents Against Interest Income Continuing to College Students of Class XI Computer Engineering and Networks Sedayu SMK 1 Academic Year 2013/2014. Research journal. Yogyakarta: Yogyakarta State University

Daughter Dance, Indriyani. 2015. Effect of Motivation and Economic Status of Families against Interests Continuing Education

toCollege.Research journal. Yogyakarta: Yogyakarta State University

Riadi, Muchlisin. 2016. Definition and Functions of Human ResourceManagement.Access ed through: http://www.kajianpustaka.co m/2016/02/pengertian-danfungsi-manajemen-sumberdaya-manusia.html on October 1, 2016

Rokhimah, Siti. 2015. Influence of Social Support and Self Efficacy against Interest in Continuing Education to College Students of SMAN 1 Tenggarong Seberang. Research journal. Samarinda: University of Mulawarman

Setiawan, Nasrul. 2013. The concept of Binary Logistic Regression / dichotomy. Accessed through:

http://statistikceria.blogspot.c o.id/2013/01/konsep-regresi$\underline{\text { logistik-biner-dikotomi.html }}$ on October 1, 2016
Slameto. 2010. Learning and FactorsAffecting.Jakarta: PT. Rineka Cipta

Soetjiningsih. 2004. Growth of Youth and ItsProblems.Jakarta: Sagung Seto

Sugihartono. 2007. EducationalPsychology.Yogy akarta: UNY Press

Sugiyono. 2016. Quantitative Research Methods, Qualitative and $R \& D$. Bandung: Alfabeta

Suharsimi Arikunto. 2010. Research Procedure A Practical Approach Revised Edition,2010.Jakarta: PT. Rineka Cipta

Sunarto, General Hartono. 2002. Development ofStudents.Jakarta: Rineka Cipta

Tatik Suryani. 2008. ConsumerBehavior.Yogyakar ta: Graha Ilmu

Thea, Addhin. 2013. Research Methodology. Accessed through:

http://addhintheas.blogspot.co .id/2013/04/metode-surveidalam-penelitian.html on July 20, 2017

Viorina Puspariani and Nur Kholis. 2012. Influence of Learning Environment, Achievement Motivation and Learning Achievement of interest to the College of Continuing Studies. Research journal. 
Yogyakarta: Yogyakarta

State University

$61 \mid P$ a g e 


\section{BIOGRAPHY}

Moch. NurandiJopa, born in Banyuwangi on March 6, 1991 from a father and a mother named Hariyanto named Jami'ah. Wife named Nina Setyowati and home addresses Hamlet Karangsari RT. 003 RW. 001 Village Kedaleman, Rogojampi Sub-district, BanyuwangiDistrict. I graduated from kindergarten Bhayangkari Rogojampi 1997, MI Islamiyah Rogojampi 2003, MTs Rogojampi 2006 and MAN Srono in 2009.

In 2010 began to continue the study of S-1 in the Faculty of Mathematics and Natural Sciences University of PGRI Banyuwangi by taking courses Program Educational Studies in Mathematics. And in 2015 went on to study for S-2 at the High School of Economics Mandala Jember to take the Master of Management and graduated in 2017.

Field studies that have been conducted a research thesis in STIE Mandala Jember in 2017 "Influence Family Economic Status, type of School and School Status of Interest to Students in Higher Education Continuing Studies Students Study on Secondary Education in the Kedaleman Village, Rogojampi Subdistrict, BanyuwangiDistrict". Activities and work experience as Teachers in Islamic High School Ihya' Ulumiddin in the Padang village, Singojuruh Sub-district, Banyuwangi District. 